medRxiv preprint doi: https://doi.org/10.1101/2020.06.22.20137034; this version posted June 23, 2020. The copyright holder for this preprint (which was not certified by peer review) is the author/funder, who has granted medRxiv a license to display the preprint in perpetuity.

All rights reserved. No reuse allowed without permission.

\title{
Molecular Detection of bla OXA-48 Gene Encoding Carbapenem Resistance Pseudomonas aeruginosa Clinical Isolates from Khartoum State Hospitals, Sudan
}

Doha Omer Ali and Mohamed M.A.Nagla*

Department of Medical Microbiology, Faculty of Medical Laboratory Sciences, Al-Neelain University, Khartoum, Sudan

*Corresponding author: nag.mas@hotmail.com

\begin{abstract}
Abatract
Carbapenem resistance in Pseudomonas.aeruginosa is particularly worrisome because this class of $\beta$-lactam represents the last therapeutic resource for control of bacterial infection.So this study aimed to detect the frequency of bla OXA-48 resistance gene among Pseudomonas aeruginosa clinical isolates during the period from November 2018 to November 2019.

Hundred Pseudomonas aeruginosa clinical isolates, 81 carbapenems (imipenem meropenem) resistant and 19 carbapenems sensitive were collected from Omdurman Teaching Hospital, Fedail Hospital and Soba Teaching Hospital in Khartoum State-Sudan. All isolates were re-identified using conventional bacteriological techniques, their susceptibility to carbapenems were tested using Kirby-Bauer method for confirmation and investigated for the presence of the bla OXA-48 gene using conventional PCR technique.

$60(60.0 \%)$ out of 100 Pseudomonas aeruginosa clinical isolates were positive for blaOXA-48 gene. Out of 81 carbapenem resistant isolates 54(66.7\%) were positive for bla OXA-48 gene, while among the (19) carbapenem sensitive isolates $6(31.6 \%)$ were positive for blaOXA-48 gene. There was statistically significant association between carbapenem resistant isolates and the presence of blaOXA-48 gene $(P$-value $=0.006)$.

Wound swabs were the predominant clinical samples detected harboring bla OXA-48 gene both among the sensitive 5 (83.3\%) and carbapenem resistant isolates 29(53.7) (P.value> 0.05).

Our findings revealed high frequency of bla OXA-48 among carbapenem resistant isolates so identification of bla OXA-48 producing strains and taking efforts to reduce the rate of transferring these gene between the different strains is essential for optimization of therapy and improves of patients outcomes.
\end{abstract}

Key words: P.aeruginosa, carbapenem resistant, bla OXA-48 gene, Khartoum State. 
medRxiv preprint doi: https://doi.org/10.1101/2020.06.22.20137034; this version posted June 23, 2020. The copyright holder for this preprint (which was not certified by peer review) is the author/funder, who has granted medRxiv a license to display the preprint in perpetuity.

All rights reserved. No reuse allowed without permission.

\section{Introduction}

Pseudomonas aeruginosa (P.aeruginosa) is gram negative bacterium.[1]. It is a lethal opportunistic pathogen that is a leading cause of morbidity and mortality in immunocompromised individuals [2]. It rarely found in the microbiota of healthy humans [3].The colonization rate by by P.aeruginosa significantly increases (reaching up to $80 \%$ ) in patients with chronic illnesses (e.g cystic fibrosis, sever burns) or extensive exposure to health care facilities involving interruption of protective barriers $[4,5]$. It has an intrinsic resistance to wide range of antimicrobial agents and a high capacity to attain resistance mutations and mobile genetic elements [6]. Elimination of $P$. aeruginosa has become increasingly difficult due to its remarkable capacity to resist antibiotics [2].

Carbapenem resistance in P.aeruginosa is particularly worrisome because this class of $\beta$-lactam represents the last therapeutic resource for control of bacterial infection [7]. Although porins loss and efflux pumps may contribute to the phenotype of carbapenem resistance in P.aeruginosa, Yet the most relevant resistance mechanism is the production of carbapenem -hydrolyzing enzymes ( carbapenemase)[7].

Carbapenemase producing carbapenem resistance enterobacteracea (CP- CRE) that directly break down carbapenem have been classified to various types such as class A $\beta$-lactamase (NMC, IMI, SMS, MKPC, GES), class B $\beta$-lactamase (IMP, VIM, SPM, NDM) and class D $\beta$-lactamase (OXA48) [8]. In recent years, the emergence of diverse carbapenemase in members of the family Enterobacteriaceae has become a major challenge for health care system [9].

BlaOXA-48 gene is a class D $\beta$-lactamase that possesses the ability to hydrolyze carbapenems as well as Cloxacillin and Penicillin [10]. Studies done by Carrër , et al., (2010) indicated that the blaOXA-48 gene has been found in plasmid and located between two identical insertion sequences, IS999, forming the composite transposon Tn 1999s [11]. The genetic environment of blaOXA-48 was investigated by PCR with primers specific for insertipon sequence IS1999 and for the 5' part of blaOXA-48 [11]. Recently, Nordmann et al described a new inhibitor-based biochemical assay for carbapenemase detection [12]. But detection of OXA-48 and related enzymes remains problematic, as no specific inhibitor is available. Temocillin resistance was suggested as an indicator of OXA-48 production but not for OXA-48 confirmation [13-15].

The first case of resistance mediated by OXA-48 was identified in 2001 from multi-drug resistance Klebsiella pneumoniae in Istanbul Turkey [16]. Several cases of OXA-48 producing organisms like Pseudomonas, E.coli and Cetrobacter were reported in patients from or have relation with Turkey [17].Several isolates producing OXA-48 have been involved as a source of nosocomial outbreaks 
medRxiv preprint doi: https://doi.org/10.1101/2020.06.22.20137034; this version posted June 23, 2020. The copyright holder for this preprint

$[18,19]$. Outbreak of OXA-48 was reported worldwide, disseminating from Middle Eastern countries and North Africa. Sporadic cases have been reported in Lebanon, Oman, Saudi Arabia and Kuwait. In Africa mostly in Northern African countries of Egypt, Tunisia, Libya and Morocco [20].And little is known about this problem in Sudan, as a rapid and reliable detection of carbapenemases is desirable in order to limit the spread of these enzymes Thus the present study aimed to investigate the frequency of blaOXA-48 resistant gene among carbapenem resistance $P$. aeruginosa.

\section{Materials and Methods}

\section{Design and setting}

A descriptive - cross sectional study was conducted in different Khartoum State hospitals, Sudan (Omdurman Teaching Hospital, Fedail Hospital and Soba Teaching Hospital) during the period from November 2018 to November 2019. A total of 100 Pseudomonas aeruginosa clinical isolates of known carbapenem susceptibility from different types of clinical samples (wound swabs, urine, ear swabs, sputum and high vaginal swabs) were included in this study. They represented 81 carbapenems (imipenem meropenem) resistant and 19 carbapenems sensitive.

Pseudomonas aeruginosa clinical isolates of known resistant and sensitive to both routinely used carbapenem (Meropenem and Imipenem) antibiotics were included in this study and any clinical isolates resist or sensitive to only one carbapenem antibiotics was excluded from this study. The approval and informed consent was obtained from Faculty and Department of Medical Microbiology management, Al-Neelain University and informed consent was taken from Hospitals included in this study.

\section{Phenotypic methods}

The fresh cultured colonies of P.aeruginosa clinical isolates were sub-cultured on nutrient agar and macConkey agar media to ensure purity and optimal growth. Then they were re- identified using routine culture techniques and their susceptibility to carbapenems were tested using Kirby-Bauer method for confirmation.

\section{DNA extraction}

Bacterial DNA was extracted by using boiling method. All bacterial strains were sub cultured on nutrient agar and the overnight pure bacterial growth were used. Three colonies were emulsified in Eppendorf tubes containing $200 \mu \mathrm{l}$ of the distilled water and boiled at $100{ }^{\circ} \mathrm{C}$ for 30 minutes then 
medRxiv preprint doi: https://doi.org/10.1101/2020.06.22.20137034; this version posted June 23, 2020. The copyright holder for this preprint (which was not certified by peer review) is the author/funder, who has granted medRxiv a license to display the preprint in perpetuity.

All rights reserved. No reuse allowed without permission.

centrifuged at $12000 \mathrm{rmp}$ for 15 minutes. The supernatant containing DNA was transferred to new Eppendorf tubes and stored at $-20^{\circ} \mathrm{C}[21]$

\section{PCR amplification procedure}

PCR was carried out for all isolates by using specific primer for OXA-48 gene $\mathrm{F}$ 5'GCGTGGTTAAGgATGAACA 3' R 5'CATCAAGTTCAACCCAACCG 3' of amplicon size of 177 bp [22]. Amplification was performed at final volume $25 \mu 1$ ( $5 \mu 1$ Mater mix, $5 \mu 1$ from DNA, $2 \mu 1$ primer and $13 \mu \mathrm{lD} . \mathrm{W})$. The PCR cycling conditions were as follows: an initial denaturation step of $10 \mathrm{~min}$ at $94^{\circ} \mathrm{C}$ followed by 35 cycles of $30 \mathrm{~s}$ at $94^{\circ} \mathrm{C}, 30 \mathrm{~s}$ at $55^{\circ} \mathrm{C}$ and $30 \mathrm{~s}$ at $72^{\circ} \mathrm{C}$,with a final extension of $10 \mathrm{~min},(\mathrm{Tc}-412, \mathrm{UK})$ thermo cycler machine was used.

PCR products was separated on $2 \%$ agarose gel by electrophoresis to detect specific amplified product by comparing with standard molecular weight marker 100 base pair (DNA ladder) $5 \mu 1$ of PCR product was loaded into the well. Electrophoresis was carried out at 100 Volts, 60 AMP and 30 minutes.

The amplified products of the study samples were visualized by Trans -illuminator. Photographed by a digital camera and transferred to computer data for labeling and storage.

\section{Results}

Hundred (100) P.aeruginosa clinical isolates were collected from different hospitals in Khartoum State, Sudan during the period from November 2018 to November 2019. They were obtained from different clinical samples. They represented (57) wound swabs, (24) urine, (3) ear swabs, (6) sputum and (10) high vaginal swabs (Table 1).Their identification was confirmed using conventional bacteriological techniques.

Table 1: Distribution of Pseudomonas aeruginosa clinical isolates according to type of specimens.

\begin{tabular}{|l|l|}
\hline Specimens & Frequency (\%) \\
\hline Wound swab & $57(57.0 \%)$ \\
\hline Urine & $24(24.0 \%)$ \\
\hline High vaginal swab & $10(10.0 \%)$ \\
\hline Sputum & $6(6.0 \%)$ \\
\hline Ear swab & $3(3.0 \%)$ \\
\hline Total & $100(100.0 \%)$ \\
\hline
\end{tabular}


medRxiv preprint doi: https://doi.org/10.1101/2020.06.22.20137034; this version posted June 23, 2020. The copyright holder for this preprint (which was not certified by peer review) is the author/funder, who has granted medRxiv a license to display the preprint in perpetuity.

All rights reserved. No reuse allowed without permission.

Carbapenem (Meropenem and Imipenem) susceptibility testing using disc diffusion method showed that $81(81.0 \%)$ of isolates were Meropenem and Imipenem resistant, While 19 (19.0\%) were Meropenem and Imipenem sensitive (Figure 1).



Figure 1: Distribution of carbapenem susceptibility tests among the 100 clinical isolates of P.aeruginosa.

Based on PCR result (Figure 2), 60 (60.0\%) out of 100 clinical isolates of Pseudomonas aeruginosa were positive for blaOXA-48 resistance gene (Figure 3).

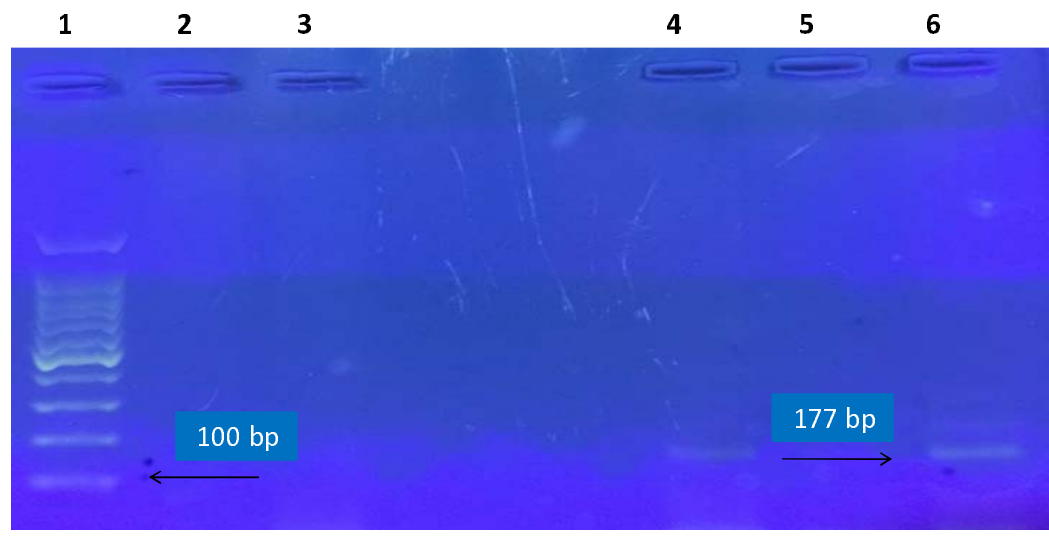

Figure 2: Amplified DNA under ultra violet light machine showing bla OXA-48 positive result. Lane 1, DNA leader $100 \mathrm{bp}$, ;Lanes 2,3, 4, 5 negative samples. Land 6 was a positive sample (typical band size of $177 \mathrm{bp}$ corresponding to the molecularsize of bla OXA-48 gene). 


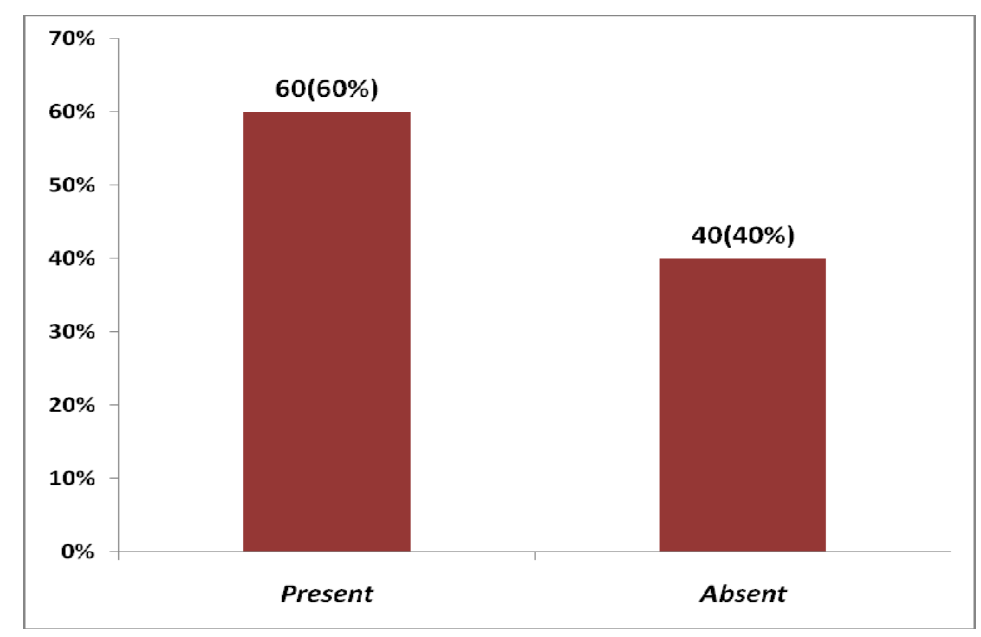

Figure 3: Frequency of blaOXA-48 resistance gene among the 100 Psaeudomonas aruginosa clinical isolates.

Out of 81 carbapenem resistant strains 54(66.7\%) were positive for bla Oxa-48 resistance gene, while among the 19 sensitive strains $6(31.6 \%)$ were positive for blaOXA-48 gene (Table 2). There was a statistically significant association between carbapenem susceptibility and the frequency of blaOXA-48 gene with ( $P$-value $=0.006)$.

Table 2: Frequency of bla OXA-48 gene according to carbapenem (Meropenem, Imipenem) susceptibility testing

\begin{tabular}{|l|l|l|l|}
\hline \multirow{2}{*}{$\begin{array}{l}\text { Carbapenem } \\
\text { susceptibility test }\end{array}$} & \multicolumn{2}{|c|}{ OXA-48 gene } & \multirow{2}{*}{ Total } \\
\cline { 2 - 3 } & Present & Absent & \\
\hline Resistance & $54(66.7 \%)$ & $27(33.3 \%)$ & $81(100.0 \%)$ \\
\hline Sensitive & $6(31.6 \%)$ & $13(68.4 \%)$ & $19(100.0 \%)$ \\
\hline Total & $60(60.0 \%)$ & $40(40.0 \%)$ & $100(100.0 \%)$ \\
\hline$P$-value & 0.006 & & \\
\hline
\end{tabular}

Table (3) showed that the frequency of blaOXA-48 gene among the resistant strains was most common among wound swabs 29 (53.7\%) followed by urine 14 (25.9\%) (P value > 0.05), similar, it was most frequent among wound swabs 5 (83.3\%) followed by urine 1 (16.7\%) among the sensitive 
medRxiv preprint doi: https://doi.org/10.1101/2020.06.22.20137034; this version posted June 23,2020 . The copyright holder for this preprint (which was not certified by peer review) is the author/funder, who has granted medRxiv a license to display the preprint in perpetuity.

All rights reserved. No reuse allowed without permission.

strains (P value > 0.05) (Table 3-4). There was a statistically insignificant association between the frequency of blaOXA-48 gene and the type of specimens.

Table 3: Frequency of carbapenemase bla OXA-48 gene among the carbapenem resistant strains of P.aerginosa according to the type of specimens

\begin{tabular}{|l|l|l|l|}
\hline \multirow{2}{*}{ Specimens } & \multicolumn{2}{|c|}{ OXA-48 gene } & \multirow{2}{*}{ Total } \\
\cline { 2 - 3 } & Present & Absent & \\
\hline Wound swab & $29(53.7 \%)$ & $15(55.6 \%)$ & $44(54.3 \%)$ \\
\hline Urine & $14(25.9 \%)$ & $7(25.9 \%)$ & $21(25.9 \%)$ \\
\hline Ear swab & $2(3.7 \%)$ & $1(3.7 \%)$ & $3(3.7 \%)$ \\
\hline Sputum & $5(9.3 \%)$ & $1(3.7 \%)$ & $6(7.4 \%)$ \\
\hline High vaginal swab & $4(7.4 \%)$ & $3(11.1 \%)$ & $7(8.6 \% 0$ \\
\hline Total & $54(100.0 \%)$ & $27(100.0 \%)$ & $81(100.0 \%)$ \\
\hline$P$-value & 0.903 & & \\
\hline
\end{tabular}

\section{Discussion}

Carbapenem resistance mediated by carbapenemases is an important issue in infection control programmers [23]. BlaOXA-48 represents the main enzyme among OXA $\beta$-lactamases isolated around the world [24].

In the present study it was found that among the total (100) clinical isolates, the most common isolates were from wound swab specimens, because Pseudomonas aeruginosa leading to cause of health care acquired infections most commonly associated with wound infections [25].

In the current study the frequency of bla OXA-48 resistance gene was $60 \%$ out of 100 Pseudomonas aeruginosa clinical isolates. Our result was higher than that study done in Sudan by Mohamed ,et al., (2018) [26] it was found out of 67 P. aerugenosa clinical isolates $22.4 \%$ were positive for bla OXA-48 resistance gene by real time PCR, This may be due to differences in sample size.

Among (81) carbapenem resistant isolates 54 (66.7\%) were positive for blaOXA-48 resistance gene $(\mathrm{P}$ value $<0.05)$. It was noted that the absence of bla OXA-48 resistance gene among the $27(33.3 \%)$ resistant strains may be due to impermeability, which arise via the loss of the Opr D porin, the up-regulation of active efflux pump system present in cytoplasmic membrane of the 
medRxiv preprint doi: https://doi.org/10.1101/2020.06.22.20137034; this version posted June 23, 2020. The copyright holder for this preprint

bacteria and bla OXA-48 resistance gene encoded on mobile genetic elements, it has ability to transfer from one bacterium to another [27].Or they may possess other type of carbapenemase enzymes rather than bla OXA-48 gene. While among the (19) carbapenem sensitive isolates, 6 (31.6\%) were positive for bla OXA-48 resistance gene. The presence of resistance gene among the sensitive strains may indicates that there might be a hidden bla OXA-48 gene among them which cannot be diagnosed by phenotypic tests as mentioned in study done by Adam et al. (2018) [28]

The present study showed that there was a statistically insignificant association between the frequency of blaOXA-48 gene and the type of specimens, although there was a high frequency of bla OXA-48 resistance gene among wound swabs than other type of specimens. This may be due to the large sample size of wound swabs compared with other specimens, and P.aeruginosa was most commonly associated with wound infections.

\section{Conclusion:}

In the present work, the significant high frequency of bla Oxa-48 resistance gene among the resistance strains may indicates that it is a main source of initiating resistance among these strains, while its presence among carbapenem sensitive isolates suggesting the occurrence of silent gene, that encoded in a movable genetic elements (plasmid), there for, it play a key role in the transfer of horizontal resistance gene from one bacterium to another. Therefore prevention and control programs of carbapenem resistant should be performed to prevent the spread of carbapenemase producers, which includes appropriate use of antimicrobials and facility-level prevention strategies, as recommended by CDC (Centers for Disease Control and prevention).

Wound swabs were the predominant specimens harboring bla OXA-48 gene followed by urine samples.

\section{References}

1. Chang HH, Cohen T, Grad YH, Hanage WPO, Brien TF, Lipsitch M (2015) Origin and proliferation of multiple-drug resistance in bacterial pathogens.Microbiology and Molecular Biology Review,79(1):101-16.

2. Zheng P, Renee R, Bernard RG, Tong-Jun L, Zhenyu C (2019). Antibiotic resistance in Pseudomonas aeruginosa: mechanisms and alternative therapeutic strategies. Biotechnology advances, 37: 177-192. 
3. Estepa V, Rojo-Bezares B, Torres C., Saenz Y (2014). Faecal carriage of pseudomonas aerginosa in healthy humans; antimicrobial susceptibility and global genetic lineages. Federation of European Microbiological Societies Microbiology Ecology 89(1): 15-9.

4. Ciofu O, Tolker-Nielsen T, Jensen PO, Wang H, Hoiby N (2015). Antimicrobial resistance, respiratory tract infections and role of biofilms in lung infections in cystic fibrosis patients. Advanced Drug Delivey Review, 85:7-23.

5. Gomez-Zorrilla S, Camoez M, Tubau, F., Periche E, Cañizares R, Dominguez MA, et al.,(2014). Antibiotic pressure is major resik factor for rectal colonization by multi drugresistance pseudomonas aeruginosa in critically ill patients. Antimicrobial agents Chemotherapy, 58 (10) 63-70.

6. Acharya M, Joshi PR, Thapa K (2017) Detection of metallo-beta lactamases-encoding genes among clinical isolates of pseudomonas aeruginosa in a terrtiary care hospital,Kathmandu, Nepal. BMC Research Notes, 10 (1): 718.

7. Toval F, Guzman A, Madriz V (2015) Predominance of carbopenem-resistant pseudomonas aeruginosa isolates carrying bla IMP and blaVIM metallo-Beta lactamase in amajor hospital in Costa Rica. Journal of Medical Microbiology, 64(1): 37-43.

8. Huang S, Liu M, Lin C, Shi Z (2014) Molecular surveillance and clinical outcomes of carbapenem-resistant Escherchia coli and Klebsiella pneumonia infection. Journal of Microbiology, Immunology and Infection, 47(3):187-196.

9. Sahuquillo-Arce JM, Hernández-Cabezas A, Yarad-Auad F, Ibáñez-Martínez E, Falomir-Salcedo P, Ruiz-Gaitán A (2015) Carbapenemases: a worldwide threat to antimicrobial therapy. World J Pharmacol,4(1): 75-95.

10. Poirel L, Marque S, He'ritier C, Segonds C, Chabanon G, Nordmann P ( 2005) . OXA58, a novel class D (beta)-lactamase involved in resistance to carbapenems in Acinetobacter baumannii. Antimicrobial. Agents and Chemotherapy,49 (1): 202-208.

11. Carrër A, Poirel L, Yilmaz M, Akan OA, Feriha C, Cuzon G, et al., (2010). Emerging spread of OXA-48-encoding plasmid from Turkeyand beyond. Antimicrob Agents and Chemother,54: 1369-73.

12. Florian P, Maurer; Claudio, C.; Chantal, Q.; Guido, V.; Bloemberg and Michael, H., (2015). Evaluation of Carbapenemase Screening and Confirmation Tests with 
medRxiv preprint doi: https://doi.org/10.1101/2020.06.22.20137034; this version posted June 23, 2020. The copyright holder for this preprint (which was not certified by peer review) is the author/funder, who has granted medRxiv a license to display the preprint in perpetuity. All rights reserved. No reuse allowed without permission.

Enterobacteriaceae and Development of a Practical Diagnostic Algorithm. Journal of Clinical. Microbiology, 53: 95-104.

13. European Committee on Antimicrobial Susceptibility Testing (2013) Guidelines for detection of resistance mechanisms and specific resistances of clinical and /or epidemiological importance .Version 1.0. European committee on antimicrobial susceptibility testing, Basel, Switzerland.

14. Dijk KV, Voets GM, Scharringa J, Voskuil S, Fluit AC, Rottier WC, Leverstein-Van Hall MA, Cohen Stuart, JWT (2014) A disc diffusion assay for detection of class A, B and OXA-48 carbapenemases in Enterobacteriaceae using phenyl boronic acid, dipicolinic acid and temocillin. Clin Microbiol Infect, 20: 345-349.

15. Tijet N, Boyd D, Patel SN, Mulvey MR, Melano RG (2013) Evaluation of the Carba NP test for rapid detection of carbapenemase-producing Enterobacteriaceae and Pseudomonas aeruginosa. Antimicrobial Agents and Chemother, 57: 4578-4580.

16. Laurent P, Ana S, Potron, Patrice N (2012) OXA-48-like carbapenemases: the phantom menace. Journal of Antimicrob Chemother, 67: 1597-1606.

17. Livermore DM, Woodford N (2006). The $\beta$-lactamase threat in Enterobacteriaceae, Pseudomonas and Acinetobacter. Trends in Microbiology,14(9): 413-420

18. Carre"r A, Poirel L, Eraksoy H, Cagatay AA, Badur S, Nordmann P (2008) Spread of OXA-48-positive carbapenem-resistant Klebsiella pneumoniae isolates in Istanbul, Turkey. Antimicrobial. Agents and Chemotherapy. 52:2950-2954.

19. Cuzon, G, Ouanich J, Gondret R, Naas T, Nordmann P (2011). Outbreak of OXA-48positive carbapenem-resistant Klebsiella pneumoniae isolates in France. Antimicrob. Agents Chemother, 55(5): 2420-2423

20. Pasteran F, Tijet N, Melano RG, Corso A (2015). Simplified protocol for carba NP test for enhanced detection of carbapenemase producers directly from bacterial cultures. Journal of Clinical Microbiology, 53 (12): 3908-3911.

21

Dahab RA, Alamin AM, Altayb HN (2017). Phenotypic and genotypic detection of carbapenemase enzymes producing gram negative bacilli isolated from patients in Khartoum state. F1000 Research, 6: 16-56. 
22. Monteiro J, Widen RH, Pignatari AC, Kubasek C, Silbert S (2012). Rapid detection of carbapenemase genes by multiplex real time PCR. Journal of Antimicrob Chemother, 67 (4): 906-9.

23. Peter S, Lacher A, Marschal M, Hölzl F, Buhl M, Autenrieth I, et al., (2014) . Evaluation of phenotypic detection methods for metallo- $\beta$-lactamases (MBLS) in clinical isolates of Pseudomonas aeruginosa. European Journal of Clinical Microbiology \& infectious Diseases, 33(7):33-41.

24. Nordmann, P.; Naas, T. and Poirel, L., (2011) Global spread of carbapenemase producing Enterobacteriaceae . Emerging Infectious Diseases, 17 (10): 1791-1798.

25. Yagoup MA, Taha. AA, Mubarak AK, Abdlla AE, Ournasseir ME, Abosalif KOA, et al. (2018) Drugs-Resistant Pseudomonas aeruginosa Isolated from Various Clinical Specimens in Khartoum, Sudan. P J M H S, 2 13(2): 441-444.

26. Mohamed SER, Alobied A, Hussien WM, Saeed MI (2018) blaOXA-48 Carbapenem Resistant Pseudomonas aeruginosa Clinical Isolates in Sudan. Journal of Advances in Microbiology 10 (4): 1-5.

27. Murphy TA, Simm AM, Toleman MA, Jones RN, Walsh TR (2003). Biochemical characterization of the acquired metallo- $\beta$-lactamase SPM-1 from Pseudomonas aeruginosa. Antimicrobial Agents and Chemotherapy, 47 (2) : 582-7.

28. Adam MA, Elhag WI (2018). Prevalence of Metallo-beta lactamase Acquired Genes among Carbapene ms Susceptible and Resistant Gram Negative Clinical Isolates Using Multiplex PCR. BMC infectious Diseases, 18 (1): 668. 


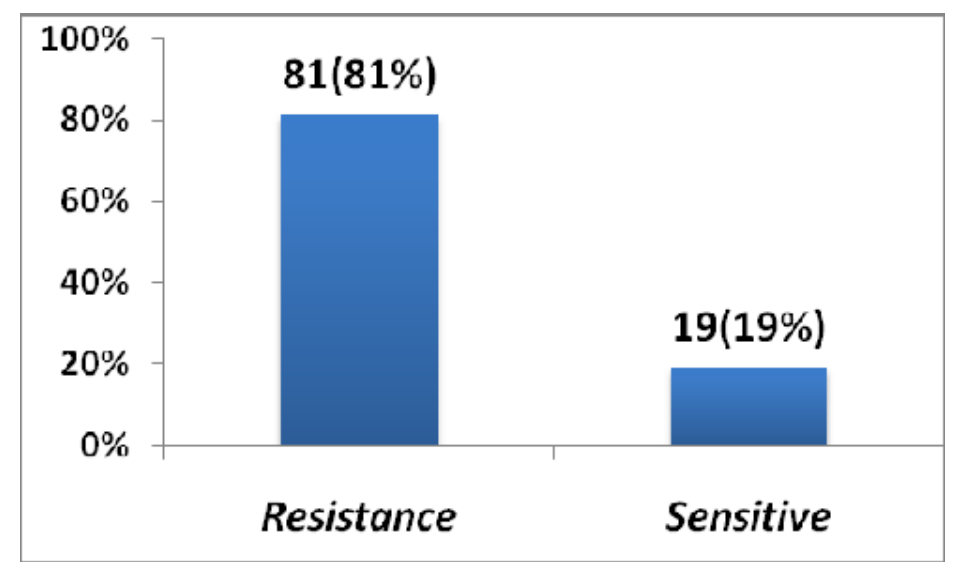

Figure 1: Distributionof carbapenem susceptibility tests among the 100 clinical isolates of P.aerugino

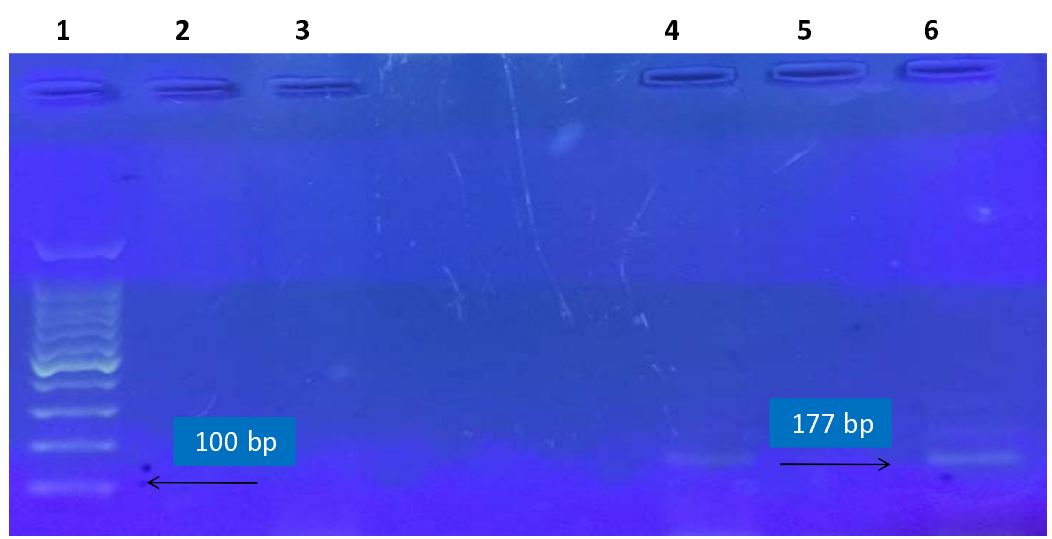

Figure 2: Amplified DNA under ultra violet light machine showing bla OXA-48 positive result. Lane 1, DNA leader $100 \mathrm{bp}$, ;Lanes 2,3, 4, 5 negative samples. Land 6 was a positive sample (typical band size of $177 \mathrm{bp}$ corresponding to the molecularsize of bla OXA-48 gene). 
medRxiv preprint doi: https://doi.org/10.1101/2020.06.22.20137034; this version posted June 23, 2020. The copyright holder for this preprint (which was not certified by peer review) is the author/funder, who has granted medRxiv a license to display the preprint in perpetuity.

All rights reserved. No reuse allowed without permission.

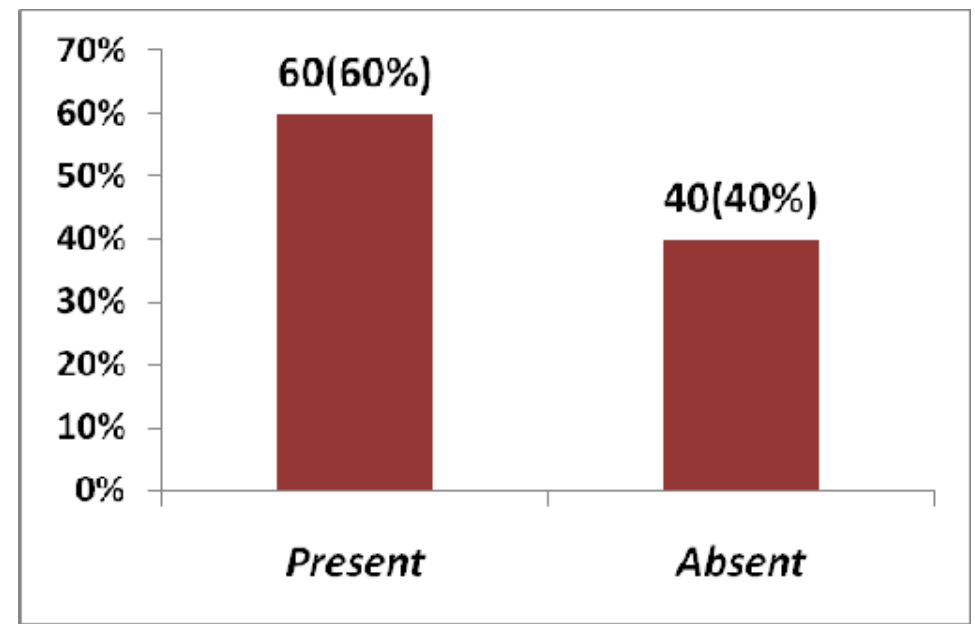

Figure 3: Frequency of blaOXA-48 resistance gene among the 100 Psaeudomonas aruginosa clinical isolates. 